\title{
Magnesium: An Intervention for Attention Deficit Hyperactivity Disorder
}

\section{Laura Terrazas}

Department of Nutritional Sciences, Rutgers University 310 W Hamilton Ave Campbell, CA. 95008, USA

*Corresponding author: Laura T, Department of Nutritional Sciences, Rutgers University 310 W Hamilton Ave Campbell, CA. 95008 USA, Tel: +831-334-3938; E-mail: lauraterrazas2@gmail.com

Received date: June 09, 2017; Accepted date: June 13, 2017; Published date: June 20, 2017

Copyright: (c) 2017 Laura T. This is an open-access article distributed under the terms of the Creative Commons Attribution License, which permits unrestricted use, distribution, and reproduction in any medium, provided the original author and source are credited.

\section{Retraction Note:}

The article entitled "Magnesium: An Intervention for Attention Deficit Hyperactivity Disorder" has been accepted for publication in the Vitamins \& Minerals considering the statements provided in the article as personal opinion of the author which was found not having any conflict or biasness towards anything. As the article was a perspective one, information provided by the author was considered as an opinion to be expressed through publication.

Soon after the publication of the paper, we witnessed some serious concerns and many of them argued that the paper is a personal perspective and had not discussed any relevant ethical issue considered under the journal scope. Moreover, the paper is neither innovative nor thought provoking.

Publisher took decision to make the article online solely based on the reviewers suggestion which considered the article not but a personal opinion of the author. However, it is found that the article has some unavoidable mistakes and issues, therefore, being retracted from the journal. 
Page 2 of 4

Magnesium is currently used to treat pre-eclampsia, bronchial spasmodic asthma and cardiac dysrhythmia disease [24-28]. Adequate magnesium stores in the body are essential for normal brain function and its deficit may account for many neurological diseases [22,29-31].

Approximately $60 \%$ of the US population is deficient in magnesium and $68 \%$ do not consume the recommended daily allowance (RDA) for Magnesium see (Table 1) [21,22,29]. This is due to low magnesium levels in soil, water filtration, increased amounts of consumed processed foods, foods that block absorption, decreased supplementation, disease states, profuse sweating, and stress $[22,23,32]$. Refining and processing foods, result in the loss of $80-90 \%$ of magnesium and the promulgation of the Western Diet has increased the number of people who are deficient in magnesium worldwide $[22,29,32]$.

\begin{tabular}{|l|l|}
\hline Gender & Magnesium intake per day \\
\hline Adult Males & 420 \\
\hline Adult Females & 360 \\
\hline Boys 14-18 years old & 410 \\
\hline Girls 14-18 years old & 360 \\
\hline Youth 9-13 years old & 240 \\
\hline Children 4-8 years old & 130 \\
\hline Children 1-3 years old & 80 \\
\hline
\end{tabular}

Table 1: The Recommended Daily Allowance (RDA) for Magnesium $\mathrm{mg} /$ day [21].

\section{Assessing magnesium in the body}

Evaluating magnesium in the body is challenging and magnesium values are not part of routine blood panels. Normal plasma serum levels are $1.5-1.9 \mathrm{mEq} / \mathrm{L}$ or $0.75-0.95 \mathrm{mmol} / \mathrm{L}$ but may not accurately reflect total body stores $[21,22,32]$. An equilibrium is maintained in the blood by resorbing magnesium from the bone stores. Approximately $0.3 \%$ of total body magnesium is present in serum with $50-60 \%$ in boney stores [22,33]. Homeostasis is ensured with resorption from these stores and when serum levels are low [22,23,33-35]. When total body magnesium is significantly depleted it may take weeks or years to replenish $[32,35]$.

As serum magnesium levels don't always reflect total body magnesium stores, an easy and accurate method that more closely measures total body magnesium is needed. Several studies have suggested a more appropriate way to measure red blood cell magnesium levels or perform magnesium load testing [22,23,32,33,36]. A more recent comparison study looking at serum, red blood cell and hair magnesium measurements found that hair levels are a better surrogate for total body magnesium stores [37]. In a further study by El Baza et al. it was shown that using Coupled Mass Spectroscopy (ICP-MS), to measure hair magnesium levels correlated most closely with total body stores. Unfortunately, this test is only offered in limited locations and is not cost effective [38].

\section{Discussion}

\section{Influence of magnesium on learning disabilities and mental health}

Magnesium is a crucial mineral and appropriate levels in the body are essential for normal cognitive function and mental health $[22,29,39]$. This is true for all people but may be more so for those who suffer from ADHD. Seventy-two to $96 \%$ of those diagnosed with ADHD have been found to be significantly deficient in magnesium $[37,38]$. Studies have shown that in these patients, supplementation with magnesium improves attention and working memory and decreases anxiety, depression and emotional dysregulation [14,17,22,29,38-42]. El Baza et al. has suggested that magnesium deficiency may be at the root of the behavioural manifestations seen in patients with ADHD [38]. This may be multifactorial and related to the fact that magnesium's inhibitory role neuromuscular junction $[31,38]$. Magnesium deficiency may also lead to dysfunction of the amygdala, which may increase anxiety and depression and in turn lead to hypothalamic dysregulation and the ability to process information, further decreasing working memory. This is thought to be mediated by magnesium's effect at the level of the N-methyl-D- aspartate (NMDA) receptors $[8,22,31,38-40,43]$.

$\mathrm{N}$-methyl-D- aspartate (NMDA) is a common receptor that has both inhibitory and excitatory function in different regions of the brain $[22,39,43]$. It is also involved in controlling synaptic plasticity, mood, learning and memory. The interplay between different receptors in the brain is mediated by ion fluctuations and low magnesium levels play a role $[8,22,42,43]$. When magnesium stores are low, $\gamma$-aminobutyric acid (GABA) receptor function is inhibited and may lead to the behavioural inability to calm one's self efficiently $[22,43]$. This chain of events this thought to cause a decrease in neural plasticity, learning and memory, as well as depression and anxiety [22]. Eby notes that $60 \%$ of clinical depression is considered treatment resistant and sites the imbalance of the NMDA receptor as a possible cause [29]. In addition, NMDA may create an over-excitability in the synaptic transmission and lead to the formation of reactive oxygen species (ROS) to form which may cause neuronal death $[22,29,43,44]$. Mechanisms which inhibit this over-excitability of NMDA receptors may induce neuroprotection $[22,44]$. In traumatic brain injury (TBI), ROS formation is common and in rat studies magnesium supplementation is thought to be neuroprotective and has been shown to improve both cognitive and motor function but these results could not be reproduced in human studies [22,44].

In 1921, magnesium was first used to treat depression [22,41] Jorgensen et al. showed that magnesium restriction led to depression in as little as six weeks [30]. Additionally, Ghafari et al. found altered NMDA receptor function not only cause depression but reduced the ability of the amygdala-hypothalamic receptors to receive information and impaired learning and spatial memory. They felt this was mediated by elevated glutamate levels [31]. Pochwat et al. found magnesium supplementation alleviated generalized depression and depression from CMS [8]. Those with ADHD are in a constant state of CMS which may lead to depression. Through these mechanisms magnesium therapy may be a solution to decrease depression and anxiety and increase learning ability, without the negative side effects of traditional medications and at significantly lower cost. 


\section{Implications for practice and research}

While stimulant drugs do help reduce some of the symptoms of $\mathrm{ADHD}$, though these drugs may not be targeting one of the main problems which is low magnesium. Stimulant medications excite the prefrontal cortex and increase working memory. This can decrease symptoms of ADHD. These drugs increase other disorders within the body though, some of which may be mediated by magnesium deficiency $[7,20]$. No research had been found on this and therefore this is an area of need.

There are very few studies that assess both behavioural and cognitive function associated with magnesium treatment [38]. A large, randomized, controlled study is required to investigate whether magnesium supplementation can decrease the symptoms of ADHD, mitigate the negative behaviours and increase learning. Additionally, investigation is required to determine an accurate, cost effective means to measure magnesium status in the body. Finally, clarification of the dosage and most bioavailable form of magnesium treatment is needed. With any future research, treatment compliance rates should also be measured especially for those with comorbid psychiatric disorders. Magnesium may be a better solution than stimulant drugs to decrease the symptoms of depression and anxiety and increase learning ability, without the negative clinical side effects at significantly lower cost.

\section{Acknowledgment}

I would like to express great appreciation to Dr. Ruth Leyse-Wallace and Jennifer R. Bridenbaugh MS, RDN, CNSC, Assistant Professor Rutgers University, School of Health Professions.

\section{References}

1. Bloom B, Cohen RA, Freeman G (2010) Summary health statistics for U.S. children: National Health Interview Survey. National Center for Health Statistics 247: 1-82.

2. https://www.cdc.gov/ncbddd/adhd/data.html

3. Visser SN, Danielson ML, Wolraich ML (2016) Vital Signs: National and State-Specific Patterns of Attention Deficit/Hyperactivity Disorder Treatment Among Insured Children Aged 2-5 Years - United States, 2008-2014. MMWR Morb Mortal Wkly Rep 65: 443-450.

4. Blum L (2007) Mother-Blame in The Prozac Nation Raising Kids with Invisible Disabilities. Gender \& Society 21: 202-226.

5. ADHD Institute. Epidemiology (2017) Retrieved on March 29, 2017.

6. Pochwat BS, Sowa-Kucma M, Siwek A, et al (2014) Antidepressant-like activity of magnesium in the chronic mild stress model in rats: alterations in the NMDA receptor subunits. Int Jou Neuropsychopharmacology 17: 393-405.

7. Prevatt F, Dehili V, Taylor N, Marshall D (2012) Anxiety in College Students With ADHD Relationship to Cognitive Functioning. J of Atten Disord 19: 222-230.

8. Richardson M, Moore DA, Wernan-Jones R, Thompson-Coon J, Ukoumunne OC, et al. (2015) Non-pharmacological interventions for attention-deficit/hyperactivity disorder (ADHD) delivered in school settings: systematic reviews of quantitative and qualitative research. Health Technol Assess 19: 1-470.

9. Dan O, Raz S (2015) The relationships among ADHD, self-esteem, and test anxiety in young adults. J Atten Disord 19: 231-239.

10. Ferrin M, Vance A (2014) Anxiety and depressive symptoms on working memory components in children and adolescents with ADHD combined type and ADHD inattentive type. Eur Child Adolesc Psychiatry 23: 1161-1173.

11. Mrug S, Hoza B, Gerdes AC (2001) Children with Attention-Deficit/ Hyperactivity Disorder: Peer Relationships and Peer-Oriented
Interventions. New Directions for Child and Adolescent Development 91: 51-78.

12. Docking K, Muro N, Cordier R, Ellis P (2013) Examining the language skills of children with ADHD following a play-based intervention. Child Language Teaching and Therapy 29: 291-304.

13. Jarrett MA (2016) Attention-deficit/hyperactivity disorder (ADHD) symptoms, anxiety symptoms, and executive functioning in emerging adults. Psychol Assess 28: 245-250.

14. Ginsberg Y, Hirvikoski T, Lindefors N (2010) Attention Deficit Hyperactivity Disorder (ADHD) among longer-term prison inmates is a prevalent, persistent and disabling disorder. BMC Psychiatry 22: 112.

15. Cahill BS, Coolidge F, Segal D, Klebe K, Marle P, et al. (2012) Overmann K, Prevalence of ADHD and Its Subtypes in Maleand Female Adult Prison Inmates. Behav Sci Law 30: 154-166.

16. Fredriksen M, Dahl A, Martinsen E, Klungsoyr O, Haavik J, et al. (2014) Effectiveness of one-year pharmacological treatment of adult attentiondeficit/hyperactivity disorder (ADHD): an open-label prospective study of time in treatment, dose, side-effects and comorbidity. Eur Neuropsychopharmacol 24: 1873-1884.

17. Subcommittee on Attention-deficit/Hyperactivity Disorder, Steering Committee on Quality Improvement and Management. ADHD: Clinical Practice Guideline for the Diagnosis, Evaluation, and Treatment of Attention-Deficit/Hyperactivity Disorder in Children and Adolescents. Pediatrics 2011-2654.

18. Rubia K, Alegria AA, Cubillo Al, Smith AB, Brammer MJ, et al. (2014) Effects of Stimulants on Brain Function in Attention-Deficit/ Hyperactivity Disorder: A Systematic Review and Meta-Analysis. Biological Psychiatry 76: 616-628.

19. Fleming M, Fitton CA, Steiner MF, McLay JS, Clark D, et al. (2017) Educational and Health Outcomes of Children Treated for AttentionDeficit/Hyperactivity Disorder. JAMA Pediatrics 17: 06-91.

20. United States Department of Health and Human Services (2016) National Institutes of Health Office of Dietary Supplements. Magnesium - Health Professional Fact Sheet.

21. Baaij JH, Hoenderop JG, Bindels RJ (2015) Magnesium in man: implications for health and disease. Physiol Rev 95: 1-46.

22. Johnson S (2001) The multifaceted and widespread pathology of magnesium deficiency. Med Hypotheses 56: 163-170.

23. World Health Organization (2011) WHO Recommendations for Prevention and Treatment of Pre-eclampsia and Eclampsia. Geneva, Switzerland.

24. Rowe BH, Bretzlaff J, Bourdon C, Bota G, Blitz S, et al. (2000) Magnesium sulfate for treating exacerbations of acute asthma in the emergency department. Cochrane Database of Systematic Reviews.

25. Duley L, Abalos E (2006) Management of pre-eclampsia. BMJ 332: 463-468.

26. Bashir H, Crom D, Metzger M, Mulcahey J, Jones D, et al. (2007) Cisplatin-induced hypomagnesemia and cardiac dysrhythmia. Pediatr Blood Cancer 49: 867-869.

27. Echahidi N, Pibarot P, O’Hara G, Mathieu P (2008) Mechanisms, Prevention, and Treatment of Atrial Fibrillation After Cardiac Surgery. Journal of the American College of Cardiology 51: 793-801.

28. Eby GA, Eby KL (2010) Magnesium for treatment-resistant depression: a review and hypothesis. Med Hypotheses 74: 649-660.

29. Winther G, Jørgensen BM, Elfving B, Nielsen DS, Kihl P, et al. (2015) Dietary magnesium deficiency alters gut microbiota and leads to depressive-like behaviour. Acta neuropsychiatrica 27: 168-176.

30. Ghafari M, Whittle N, Miklósi AG, Kotlowsky C, Schmuckermair C, et al. (2015) Dietary magnesium restriction reduces amygdala-hypothalamic GluN1 receptor complex levels in mice. Brain Struct Funct 220: 2209-2221.

31. Crosby V, Elin RJ, Twycross R, Mihalyo M, Wilcock A (2013) Magnesium. J Pain Symptom Manage 45: 137-144.

32. Dalton LM, NiFhloinn DM, Gaydadzhieva GT, Mazurkiewicz OM, Leeson H, et al. (2016) Magnesium in pregnancy. Nutr Rev 74: 549-557. 
33. Sales CH, Lima JG, Lemos TM, Colli C (2011) Influence of magnesium status and magnesium intake on the blood glucosecontrol in patients with type 2 diabetes. Clinical Nutrition 30: 359-364.

34. Lambe SD, Naik PS, Patil AB (2016) Study of magnesium and surgical stress. Journal of Krishna Institute of Medical Sciences University 5 : 81-86.

35. Soriani S, Arnaldi C, Carlo L, Arcudi D, Mazzotta D Soriani S et al (1995) Serum and Red Blood Cell Magnesium Levels in Juvenile Migraine Patients. Headache 35: 14-16.

36. Kozielec T, Starobrat-Hermelin B (1997) Assessment of magnesium levels in children with attention deficit hyperactivity disorder (ADHD). Magnesium Research 10: 143-148.

37. El Baza F, AlShahawi A, Zahra S, AbelHakim R (2016) Magnesium supplementation in children with attention deficit hyperactivity disorder. Egyptian Journal of Medical Human Genetics 17: 63-70.

38. Młyniec K, Davies CL, de Aguero Sanchez IG, Pytka K, Budziszewska B, et al. (2014) Nowak G, Essential elements in depression and anxiety. Part I. Pharmacol Rep 66: 534-544.
39. Zogović D, Pešić V, Dmitrašinović G, Dajak M, Plećaš B, et al. (2014) Pituitary-Gonadal, Pituitary-Adrenocortical Hormones and IL-6 Levels Following Long-Term Magnesium Supplementation in Male Students. J of Medical Biochemistry 33: 291-298.

40. Serefko A, Szopa A, Wlaź P, Nowak G, Radziwoń-Zaleska M, et al. (2013) Magnesium in depression. Pharmacological Reports 65: 547-554.

41. Rajizadeh A, Mozaffari-Khosravi H, Yassini-Ardakani M, Dehghani A (2017) Effect of magnesium supplementation on depression status in depressed patients with magnesium deficiency: A randomized, doubleblind, placebo-controlled trial. Nutrition 35: 56-60.

42. Newcomer JW, Farber NB, Olney JW (2000) NMDA receptor function, memory, and brain aging.Dialogues in Clinical Neuroscience 2: 219-232.

43. Serefko A, Szopa A, Wlaź P, Nowak G, Radziwoń-Zaleska M, etal. (2016) Neuroprotection of taurine against reactive oxygen species is associated with inhibiting NADPH oxidases. Eur J Pharmacol 777: 129-35. 